\title{
Autonomous shipping. The future of the maritime industry?
}

\section{Wiesław Wasilewski}

\author{
University of Zielona Góra \\ E-mail: \\ w.wasilewski@wez.uz.zgora.pl \\ ORCID: 0000-0001-8772-7656
}

\author{
Katarzyna Wolak \\ University of Zielona Góra \\ E-mail: \\ kasia2157@onet.pl \\ ORCID: 0000-0002-6224-7995
}

\author{
Magdalena Zaraś \\ University of Zielona Góra \\ E-mail: \\ magdalena.d.zaras@gmail.com \\ ORCID: 0000-0002-9070-1219
}

Publication financed by: Małopolska School of Economics in Tarnów

Correspondence to:

Wiesław Wasilewski

Uniwersytet Zielonogórski

Wydział Ekonomii i Zarządzania

ul. Licealna 9

65-417 Zielona Góra

E-mail:w.wasilewski@wez.uz.zgora.pl

\begin{abstract}
The main goal of the article is to present the problems of the development of autonomous ships and to characterize the most important challenges. The article provides a description of autonomous ships and studies the existing relevant projects. It presents a spectrum of applications and possibilities of unmanned ships in the field of security. Currently, high hopes are placed on the functioning of unmanned ships. They are not only to be more economical but also to contribute to environmental protection. Developing a technology that allows the construction of ships and their safe operation is not the only task faced by enthusiasts of unmanned vessels. It is also important to develop and implement proper regulatory framework that will allow the legal operation of such ships.
\end{abstract}

Keywords: logistics, autonomous shipping, unmanned vessels, maritime industry

\section{Introduction}

Autonomous ships do not require a crew present on board. They are operated remotely by the operator or operate absolutely independently. They can contribute to increased safety on the water by performing a wide range of tasks, reducing the risk of danger to health or life.

A transition to remote-controlled and autonomous vessels will have an impact on shipping, its resources and management. This transition will affect not only the technology-related operations, but will lead to changes in the way the shipping business operates. New kinds of capabilities will be 
required and some actors may find their roles changed. Global companies' logistics chains are likely to become more integrated and adaptable using the whole fleet in an optimum way. Ongoing digitalization and autonomous technologies will create new services already along the way towards autonomous shipping. Some of these services will support existing market players and some will allow new players to enter the market. For example, in the automotive sector the self-driving car has been seen as an opportunity not only by traditional car manufacturers, but also by entrants from other technology sectors (Rolls-Royce, 2016, p. 3).

\section{Research on autonomous ships}

Currently, many studies on autonomous ships are underway in the world at the same time. The most significant ones are presented in Table 1 .

Table 1. Studies on autonomous ships

\begin{tabular}{|l|l|l|}
\hline Name of the project & Responsible entity & \multicolumn{1}{|c|}{ Characteristic } \\
\hline $\begin{array}{l}\text { Maritime Unmanned } \\
\text { Intelligence } \\
\text { in Networks } \\
\text { (MUNIN) }\end{array}$ & $\begin{array}{l}\text { collaborative } \\
\text { research project, } \\
\text { co-funded by } \\
\text { the European } \\
\text { Commissions }\end{array}$ & $\begin{array}{l}\text { investigating the technical, economic, and legal feasibility } \\
\text { of unmanned ships }\end{array}$ \\
\hline $\begin{array}{l}\text { Advanced } \\
\text { Autonomous } \\
\text { Waterborne } \\
\text { Applications } \\
\text { Initiative (AAWA) }\end{array}$ & Rolls-Royce & $\begin{array}{l}\text { bring together universities, ship designers, equipment } \\
\text { manufacturers, and classification societies to explore the } \\
\text { economic, social, legal, regulatory, and technological factors } \\
\text { which need to be addressed in order to make autonomous } \\
\text { ships a reality }\end{array}$ \\
\hline ReVolt & DNV GL & $\begin{array}{l}\text { The vessel will operate at a speed of 6 knots with a range of } \\
\text { 100 nautical miles and a cargo capacity of 100 twenty-foot } \\
\text { containers. }\end{array}$ \\
\hline $\begin{array}{l}\text { Cyber-enabled } \\
\text { ship project }\end{array}$ & Lloyd's Register & $\begin{array}{l}\text { A unique, world-class approach to providing cyber security } \\
\text { services to the marine and offshore industry. }\end{array}$ \\
\hline $\begin{array}{l}\text { Autonomous } \\
\text { Marine Operations } \\
\text { and Systems } \\
\text { (AMOS) }\end{array}$ & $\begin{array}{l}\text { Norwegian } \\
\text { University of } \\
\text { Science and } \\
\text { Technology }\end{array}$ & $\begin{array}{l}\text { The research results are being used to develop intelligent } \\
\text { ships and ocean structures, autonomous unmanned vehicles } \\
\text { (under water, on the sea surface, in air and space) and robots } \\
\text { for high-precision and safety-critical operations in harsh } \\
\text { environments. }\end{array}$ \\
\hline Yara Birkeland & Kongsberg & $\begin{array}{l}\text { A 120 TEU (Twenty-foot Equivalent Units) open top } \\
\text { container ship. It will be a fully battery-powered solution, } \\
\text { prepared for autonomous and unmanned operation. The } \\
\text { vessel will reduce NOx and CO2 emissions by reducing } \\
\text { diesel-powered truck transport by around 40,000 journeys } \\
\text { per year. }\end{array}$ \\
\hline
\end{tabular}

S o u r c e: MUNIN, 2015; Rolls-Royce, 2016; DNV, 2021; NTNU AMO, 2021; Kongsberg, 2021.

The Maritime Unmanned Navigation through Intelligence in Networks (MUNIN) started in 2012. It was funded by the European Commission, with the purpose of investigating the technical, economic, and legal feasibility of unmanned ships. MUNIN aims to develop and verify a concept for an autonomous ship, which is defined as a vessel primarily guided by automated onboard decision systems but controlled by a remote operator in a shore side control station (MUNIN, 2015). 


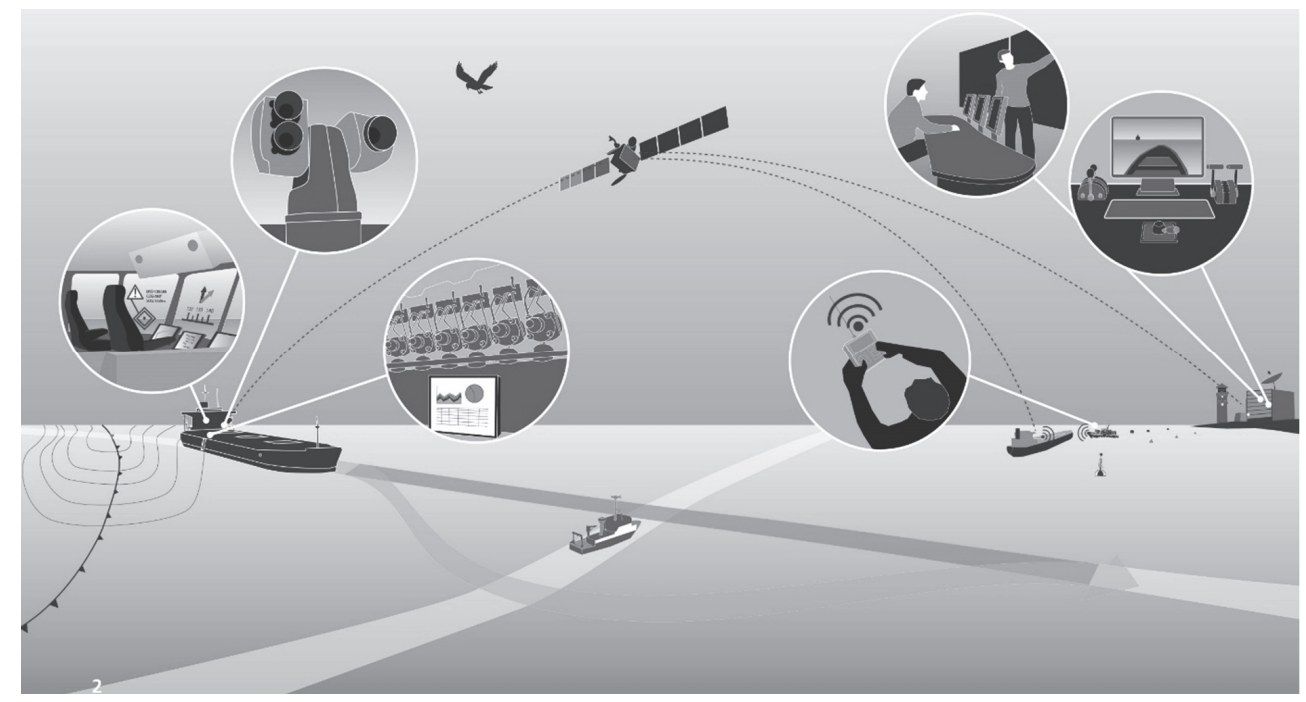

Figure 1. The Maritime Unmanned Navigation through Intelligence in Networks

S o u r c e: MUNIN, 2015.

Another example of such a project is that of the Advanced Autonomous Waterborne Applications Initiative (AAWA), launched by Rolls-Royce in 2015. It will produce the specification and preliminary designs for the next generation of advanced ship solutions (Rolls-Royce, 2016).

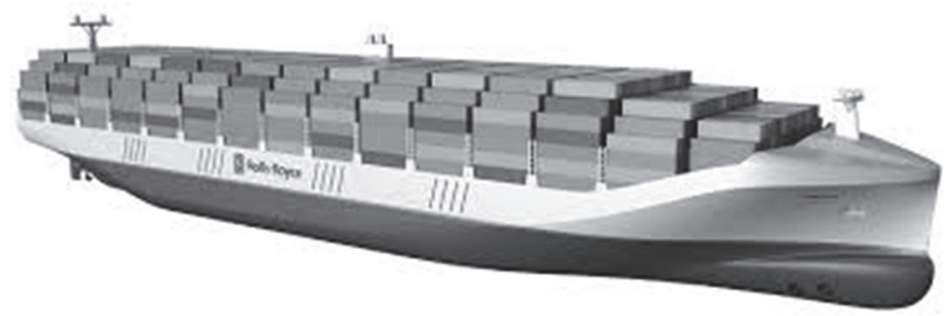

Figure 2. Advanced Autonomous Waterborne Applications Initiative

S o u r c e: Rolls-Royce, 2016.

A third project is the ReVolt, an unmanned, 60-metre-long, zero-emission, short sea vessel, developed by DNV GL. The vessel is crewless, fully battery powered, autonomous, and it offers a solution to the growing need for transport capacity (DNV, 2021). 


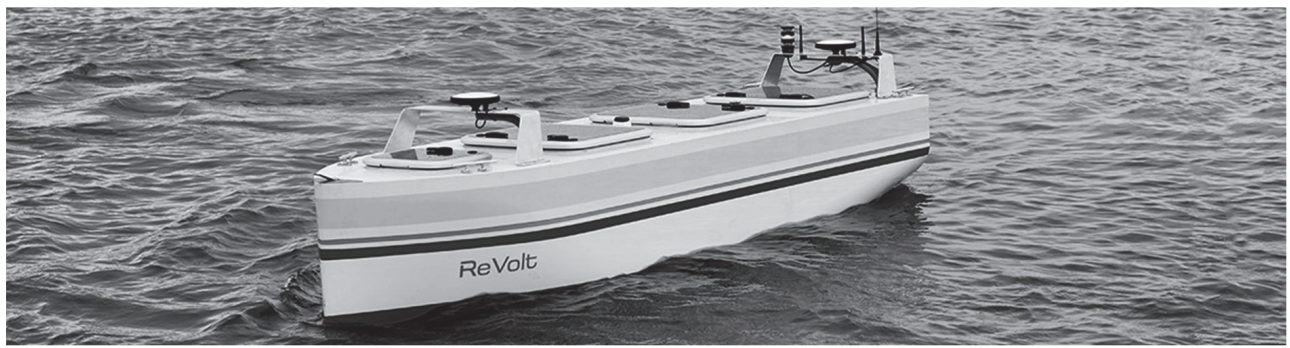

Figure 3. ReVolt

S o u r ce: DNV, 2021.

Autonomous Marine Operations and Systems (AMOS) was developed by the Departments of Marine Technology and Engineering Cybernetics at the Norwegian University of Science and Technology (NTNU) in collaboration with international and national partners. It is related to the unmanned ships and focuses on the following topics: Autonomous system and payload architectures, Coordinated operation of a sensor network of unmanned vehicles and floating nodes, Integrated underwater navigation and mapping, Autonomous object detection and tracking in marine environments using infrared sensors, Sensor-based guidance and path optimization, Coordinated and cooperative control architectures for intelligent task execution, and collision avoidance in uncertain maritime environments (Tomotsugu, 2016, p. 22; NTNU AMOS, 2021).

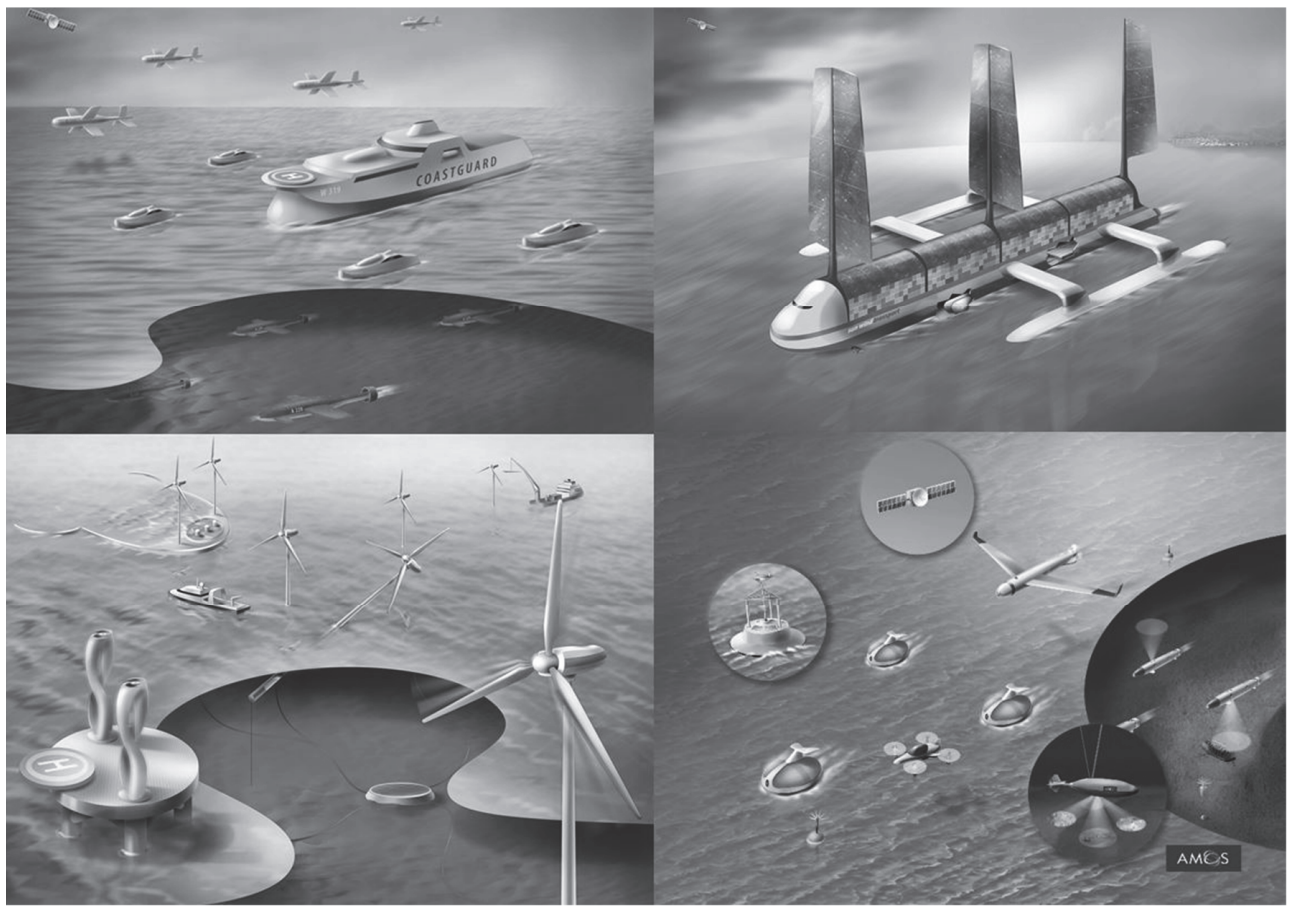

Figure 4. Autonomous Marine Operations and Systems

S o u r c e: NTNU AMOS, 2021. 
The vessel Yara Birkeland will be the world's first fully electric and autonomous container ship, with zero emissions. Kongsberg is responsible for development and delivery of all key enabling technologies including the sensors and integration required for remote and autonomous ship operations, in addition to the electric drive, battery and propulsion control systems (Kongsberg, 2021).

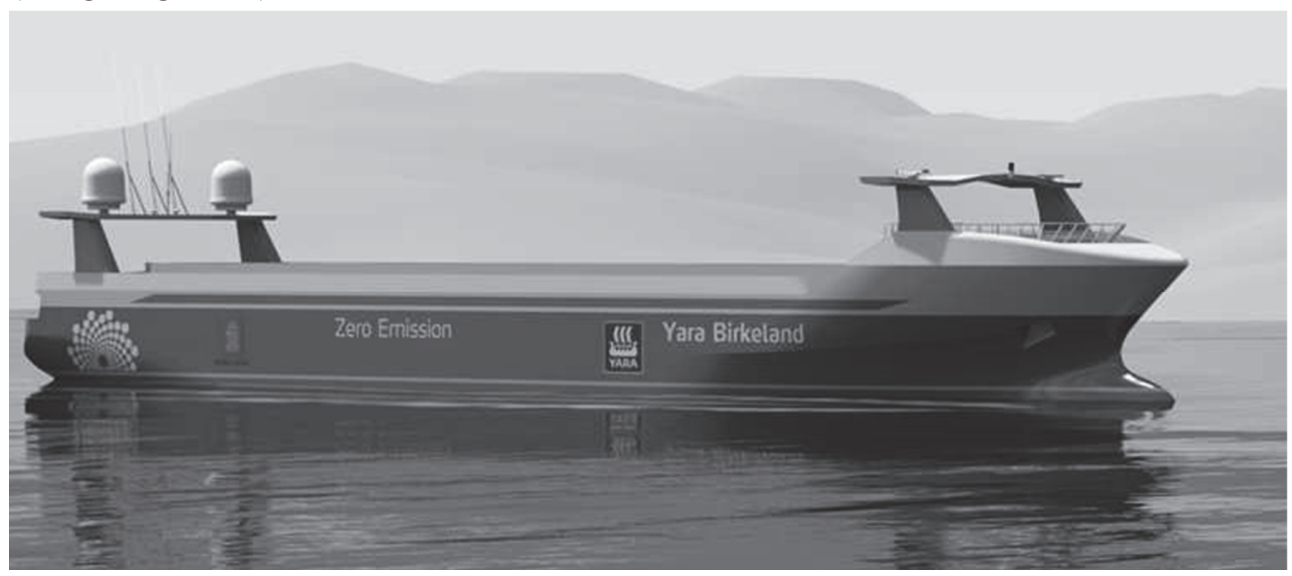

Figure 5. Yara Birkeland

S o u r c e: Kongsberg, 2021.

First we need to answer few important questions (Rolls-Royce, 2016):

- What technology is needed?

- What new risks will appear and how can they be mitigated?

- Are autonomous ships legal and who is liable in the event of an accident?

- Does a ship's master or crew necessarily have to be on board of the ship?

Unmanned ships are being developed due to exceptional technical capabilities, including cost limitations and mission time extending beyond the limits of the human body.

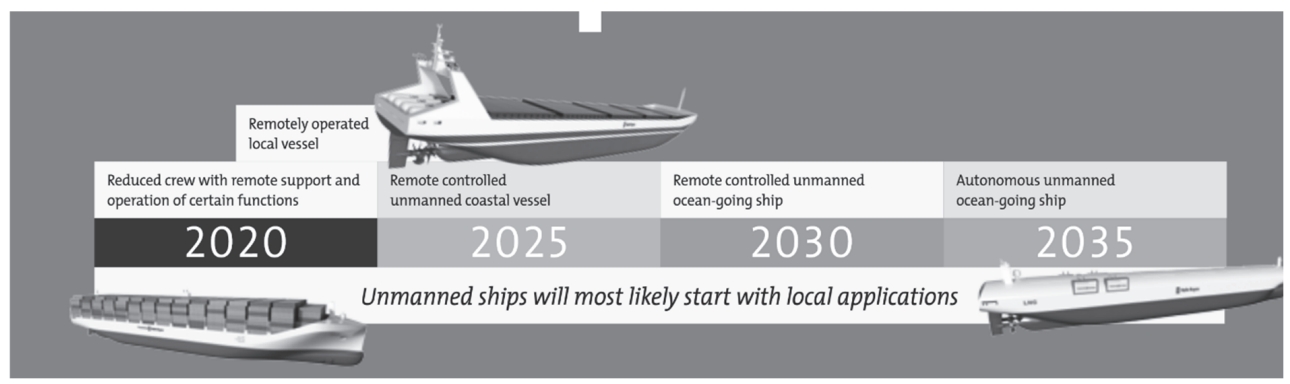

Figure 6. Unmanned ships: next steps

S o u r c e: Rolls-Royce, 2016. 
Direct benefits from using of autonomous ships are (Rolls-Royce, 2016):

- More efficient use of space in ship design;

- More efficient use of crew and their skills;

- More efficient use of fuel.

Indirect benefits occur at company and network levels in the shipping sector. Remote and autonomous shipping allows improved optimization of operations and processes. For example, optimizing processes or operations based on realtime data enables economies of scale at fleet and company level as well as reducing the likelihood of human errors, contributing both to safety and service quality. In terms of the shipping sector, autonomous shipping will recast the roles and reorganize the division of work.

\section{Development of autonomous shipping}

Autonomous ships can function independently of humans. The degrees of autonomy are presented in Table 2 .

Table 2. The degrees of autonomy

\begin{tabular}{|l|l|}
\hline \multicolumn{1}{|c|}{ Degrees of autonomy } & \multicolumn{1}{c|}{ Characteristic } \\
\hline $\begin{array}{l}\text { Degree one: Ship with automated } \\
\text { processes and decision support }\end{array}$ & $\begin{array}{l}\text { Seafarers are on board to operate and control shipboard systems and } \\
\text { functions. } \\
\text { Some operations may be automated and at times be unsupervised but } \\
\text { with seafarers on board ready to take control. }\end{array}$ \\
\hline $\begin{array}{l}\text { Degree two: Remotely controlled } \\
\text { ship with seafarers on board }\end{array}$ & $\begin{array}{l}\text { The ship is controlled and operated from another location. Seafarers } \\
\text { are available on board to take control and to operate the shipboard } \\
\text { systems and functions. }\end{array}$ \\
\hline $\begin{array}{l}\text { Degree three: Remotely controlled } \\
\text { ship without seafarers on board }\end{array}$ & $\begin{array}{l}\text { The ship is controlled and operated from another location. There are } \\
\text { no seafarers on board. }\end{array}$ \\
\hline $\begin{array}{l}\text { Degree four: Fully autonomous } \\
\text { ship }\end{array}$ & $\begin{array}{l}\text { The operating system of the ship is able to make decisions and } \\
\text { determine actions by itself. }\end{array}$ \\
\hline
\end{tabular}

S o u r c e: IMO, 2018.

The MUNIN project investigated the feasibility of unmanned, autonomous merchant vessels. The ships will be manned while departing and entering port and unmanned during ocean-passage. When unmanned, the ships will be controlled by an automatic system informed by onboard sensors allowing the ship to make standard collision avoidance manoeuvres according to international regulation. The ship will be continuously monitored by a remote shore centre able to take remote control should the automatic systems falter (Porathe, Prison and Man, 2014). It is possible to develop a standard based on experiences with autonomous cars. However, the following aspects should be noted. The size of the ship is much larger and the manoeuvrability is much smaller. Moreover, the consequences of any accidents are much more serious.

The big challenge for a future autonomous technology will be to show that an unmanned system is at least as safe as a manned ship system, and to provide the shore control operators with adequate situation awareness (Porathe, Prison and Man, 2014). A very important issue is the compliance of the manoeuvres with the international regulations on preventing collisions at sea (COLREGS) and the interaction of autonomous ships with classic manned ships. 


\section{Future}

Hereby, the autonomous vessel is described as a ship equipped "with modular control systems and communication technology to enable wireless monitoring and control, including advanced decision support systems and the capabilities for remote and autonomous operation" (Waterborne.eu, 2011). The autonomous vessels will be equipped with systems allowing self-steering by sensor-based detection of objects such as obstacles and will be able to self-initiate an action, e.g. to avoid collisions with other objects. This may be achieved by technical systems installed onboard, which use programmed algorithms and input data gathered by sensors. The introduction of the autonomous ship concept to the shipping industry might start a new era and become a game changer in terms of cost efficiency, accident prevention, and human resources (Komianos, 2018).

An autonomous ship is not necessarily unmanned. From time to time maintenance teams might be onboard during parts of the voyage to make service or repairs on systems onboard, and the ship is expected to be manned during port approach and departure (Porathe, Prison and Man, 2014).

Paradigms of applied unmanned systems can already be found in other modes of transport, such as airplanes, trains, and in the automobile industry, which is already trying to develop autonomous vehicles. However, a very distinct and serious problem exists in the shipping and maritime sectors, namely, the lack of autonomous ships' coverage and inclusion in relevant safety, security, and environmental protection conventions and regulations. The initiation of a new perspective is therefore needed before autonomous ships can be introduced to commercial shipping, in order to ensure the prevention of maritime accidents and the protection of the environment (Komianos, 2018).

There are already several small-size unmanned and autonomous crafts in the maritime sector which have been engaged in surface navigation, research and scientific activities, under water operations, and specific military activities. Proven safe, these vessels are the path towards the elimination of human error and thus accident minimization (Tomotsugu, 2016).

The development towards an unmanned and autonomous ship represents a comprehensive solution to meet those three major challenges of the maritime transport industry (Burmeister et al., 2014a):

- keep operational expenses as low as possible to facilitate efficient international trade;

- reduce environmental impact and emission of greenhouse gases;

- remove trivial operational tasks and release crew for more demanding and interesting work, to attract and retain seagoing professionals.

\section{Conclusion}

The implementation of an autonomous vessel will provide the opportunity to increase the efficiency of ship operation as well as enhance the sustainability, which is the greatest driver in any industry (United Nations, 2008). The construction of intelligent vessels would change this situation, creating a better, more profitable and, hopefully, safer shipping market. Development of autonomous vessels such as those in the MUNIN project will offer a wide-ranging solution to meet the main challenges of the maritime transport industry, resulting in a de- 
crease in the operational expenses, better environmental protection practices, and human fatigue minimization (Burmeister et al., 2014b).

This kind of ship design is so new, due to the rapid scientific developments in the maritime industry, that such vessels are not yet covered by any international rule or regulation. The International Maritime Organization (IMO) has not given any approval for this type of vessel nor has it received any proposal from the contracting governments to regulate unmanned vessels.

The implementation of the autonomous ship concept on a mass scale will have a huge impact on the efficiency of the industry, human resource management, and accident prevention. The benefits of environmental protection are also important. Although the existing maritime technology may cover any safety, environmental, and commercial concerns, the lack of a proper regulatory framework may delay the actual use of such vessels.

\section{References}

Burmeister, H. C., Bruhn, W., Rodseth, O. J., Porathe, T. (2014a). Autonomous unmanned merchant vessel and its contribution towards the e-navigation implementation: The MUNIN perspective. International Journal of e-Navigation and Maritime Economy, 1(C), 1-13. DOI: 10.1016/j.enavi.2014.12.002.

Burmeister, H. C., Wilko, C. B, Ørnulf, J. R., Porathe, T. (2014b). Can unmanned ships improve navigational safety? Transport Research Arena [online, accessed: 2021-09-15]. Retrieved from: https://publications. lib.chalmers.se/records/fulltext/198207/local_198207.pdf.

DNV. (2021). Autonomous and remotely-operated ships [accessed: 2021-07-31]. Retrieved from: www.dnv. $\mathrm{com} /$ maritime/autonomous-remotely-operated-ships/research-activities.html.

IMO. (2018). Framework for the regulatory scoping exercise for the use of Maritime Autonomous Surface Ships (MASS). MSC 100/20/Add.1, Annex 2 [online, accessed: 2021-07-31]. Retrieved from: https:// maiif.org/wp-content/uploads/2019/06/MSC-100_20-Annex-20-1.pdf.

Komianos, A. (2018). The autonomous shipping era: Operational, regulatory, and quality challenges. TransNav the International Journal on Marine Navigation and Safety of Sea Transportation, 12(2), 335-348. DOI: 10.12716/1001.12.02.15.

Kongsberg. (2021). Autonomous ship project, key facts about Yara Birkeland [online, accessed: 2021-07-31]. Retrieved from: www.kongsberg.com/maritime/support/themes/autonomous-ship-project-key-facts-about-yara-birkeland 2021.

MUNIN. (2015). D9.3: Quantitative assessment [online, accessed: 2021-07-31]. Retrieved from: http://www. unmanned-ship.org/munin/wp-content/uploads/2015/10/MUNIN-D9-3-Quantitative-assessment-CML-final.pdf.

NTNU AMOS. (2021). NTNU AMOS - Centre for autonomous marine operations and systems [online, accessed: 2021-07-31. Retrieved from: www.ntnu/edu/amos.

Porathe, T., Prison, J., Man, Y. (2014). Situation awareness in remote control centres for unmanned ships. Human Factors in Ship Design \& Operation, 26-27 February, London [online, accessed: 2021-07-31]. Retrieved from: https://core.ac.uk/download/pdf/70605914.pdf.

Rolls-Royce. (2016). Autonomous ships. The next step [online, accessed: 2021-07-31]. Retrieved from: https://www.rolls-royce.com/ /media/Files/R/Rolls-Royce/documents/\%20customers/marine/ship-intel/ rr-ship-intel-aawa-8pg.pdf.

Tomotsugu, N. (2016). Existing conventions and unmanned ships-need for changes? Malmo: World Maritime University [online, dostęp: 2021-07-31]. Retrieved from: https://commons.wmu.se/cgi/viewcontent. cgi?article $=1526 \&$ context $=$ all_dissertations.

United Nations. (2008). Achieving sustainable development and promoting development cooperation [online, accessed: 2021-07-31]. Retrieved from: https://www.un.org/en/ecosoc/docs/pdfs/fina_08-45773.pdf.

Waterborne.eu. (2011). Waterborne implementation plan. Strategic Research Agenda [online, accessed: 2021-07-31]. Retrieved from: https://www.waterborne.eu/images/documents/previous-waterborne-documents/files/wsra_2011.pdf. 


\title{
Żegluga autonomiczna. Przyszłość marynarki?
}

\begin{abstract}
Abstrakt: Artykuł definiuje funkcjonowanie żeglugi aucjonowaniu statków bezzałogowych. Mają być one nie tonomicznej i analizuje istniejące ważne projekty matylko bardziej ekonomiczne, ale także mają przyczyniać jące na celu opracowanie i wdrożenie odpowiedniej technologii. Opisano problematykę rozwoju statków autonomicznych oraz scharakteryzowano najważniejsze wyzwania. Przedstawiono spektrum zastosowań i możliwości statków bezzałogowych w dziedzinie bezpieczeństwa. Obecnie duże nadzieje pokłada się w funksię do ochrony środowiska. Opracowanie technologii pozwalającej na budowę statków i ich bezpieczną eksploatację to nie jedyne zadanie stojące przed entuzjastami żeglugi autonomicznej. Ważne jest również opracowanie i wdrożenie odpowiednich ram regulacyjnych, które pozwolą na legalną eksploatację takich statków.
\end{abstract}

Słowa kluczowe: logistyka, żegluga autonomiczna, statki bezzałogowe, przemysł morski 